\title{
Growth Promotion of Burkholderia ambifaria Associated to Nitrogen Fertilization in the Initial Development of Corn
}

\author{
Tauane Santos Brito ${ }^{1}$, Renan Pan $^{1}$, Lenir Aparecida Buss ${ }^{1}$, João Paulo Fonesi de Carvalho ${ }^{1}$, Tatiane Eberling ${ }^{1}$, \\ Alexandra da Silva Martinez ${ }^{1}$, Vandeir Francisco Guimarães ${ }^{1} \&$ Elisiana Inês Dall'Oglio Chaves ${ }^{2}$ \\ ${ }^{1}$ Agrarian Sciences Center, West of Paraná State University, Marechal Cândido Rondon, PR, Brazil \\ ${ }^{2}$ Life Sciences School, Pontifical Catholic University of Paraná, Toledo, PR, Brazil \\ Correspondence: Tauane Santos Brito, Agrarian Sciences Center, West of Paraná State University, Pernambuco \\ Street, 1777, 85960-000, Marechal Cândido Rondon, PR, Brazil. E-mail: tauane-brito@hotmail.com
}

Received: January 28, 2018 Accepted: April 19, $2018 \quad$ Online Published: May 15, 2018

doi:10.5539/jas.v10n6p123 URL: https://doi.org/10.5539/jas.v10n6p123

\begin{abstract}
Growth promoting bacteria are a potential option for sustainable cultivation with lower costs, among them Burkholderia ambifaria, whose importance is mainly due to the endophytic root colonization capacity. The objective of this work was to evaluate the effect of the inoculation of growth promoting bacteria in corn plants, in vitro and in greenhouse, with different levels of nitrogen fertilization. The PIONEER ${ }^{\circledR}$ 30F53 YH maize genotype was inoculated with Burkholderia ambifaria, with $106 \mathrm{CFU}$ per seed, in 12-liter polyethylene pots, filled with commercial substrate, prepared with the different nitrogen contents $(\mathrm{N})$, resulting in treatments with different doses of fertilization, associated or not with bacterial inoculation. After 30 and 45 days, it was evaluated: growth promotion, epiphytic and endophytic population and nitrogen accumulation. In the in vitro experiment, inoculated seeds were cultured in test tubes containing culture medium with absence and presence of nitrogen, evaluated after 7 days. The data were submitted to analysis of variance and the means were compared by the Tukey test at $5 \%$ of probability and regression. Increased nitrogen doses in inoculated plants resulted in better morphological parameters at 45 days. In vitro bacterial inoculation, in vitro, influenced the accumulation of fresh weight of shoot, root growth and development of root hair. The endophytic potential and the accumulation of nitrogen were higher in the absence of nitrogen, but lower than the absence of bacteria and the presence of nitrogen.
\end{abstract}

Keywords: endophytic bacteria, Zea mays L., soil microbiology, sustainable agriculture

\section{Introduction}

The corn (Zea mays L.) is a graminea of the Poaceae family, belonging to the $\mathrm{C}_{4}$ group of high photosynthetic rates, whose development is limited by water, temperature and solar radiation. It is necessary to offer a reasonable amount of nutrients, and in the correct periods, so that the plant can develop in a healthy way, also, biotic and abiotic stress, such ashydric deficit, high populational density, damage by pests and pathogens, among others, affecting directly the efficient use of nutrients by the plants and final yield of the crop (Cruz et al., 2010).

Biological nitrogen fixation is the most important of natural processes for use of atmospheric nitrogen in which bacteria or blue algae assimilate $\mathrm{N}_{2}$ in the form of ammonia $\left(\mathrm{NH}_{3}\right)$, which dissolves in water and forms ammonium $\left(\mathrm{NH}_{4}{ }^{+}\right)$, a form capable of being assimilated by the plants (Taiz \& Zeiger, 2013).

Plant growth promoting bacteria promote the development of plants in a variety of ways, such as the production of phytohormones, the fixation of atmospheric nitrogen, the production of siderophores, solubilizing phosphates, among others. However, this interaction with Poaceae manifests differently from what occurs in legumes and does not form fixation nodules (Figueiredo, Sobral, Stamford, \& Araujo, 2010). The inoculated plants demonstrate high utilization of the nutrients and morphological characteristics of interest superior to the controls, especially the development of the aerial part and the root system (Alvez \& Reis, 2011).

There are many ways of plant-bacteria interaction, which represent an important source of study yet to be explored. Many studies have sought to clarify the interaction between microorganisms and plants and to demonstrate their effects on agriculture and the environment, such as pest and disease control (J. R. C. Silva, Souza, Zacarone, L. H. C. P. D. Silva, \& Castro, 2008), growth promotion (Barretti, Romeiro, Mizubuti, \& 
Souza, 2009; Pereira et al., 2012), biological fixation of atmospheric nitrogen (A. V. Kuss, V. V. Kuss, Lovato, \& Lovato, 2007), tolerance to drought stress (Marcos, 2012; Santos, Sacramento, Mota, Souza, \& Azevedo Neto, 2014), rooting promotion (Marques Junior, Canellas, Silva, \& Olivares, 2008), phytohormones production (Canuto et al., 2003), among others.

Burkholderia ambifaria was the first growth-promoting bacterium to demonstrate that these microorganisms colonize the root surface, then penetrate the cells through intracellular membrane spaces, as well as formation points of secondary roots and wounds in the region of the epidermis, colonizing the stomates of some cultures (J. I. Baldani \& V. L. Baldani, 2005).

Researches with Poaceae are still recent, however, meaningful results can be observed in aerial growth, dry matter and roots increase, in crops with high nitrogen demand. The known efficiency of the biological fixation of rhizobium and legume symbiosis is not repeated in the association between growth promotion bacteria and grasses, although there are similar characteristics between the association of diazotrophic bacteria and the plant and the symbiosis with the legumes (J. I. Baldani \& V. L. Baldani, 2005). In a study carried out by Quadros (2009), ten maize hybrids inoculated with diazotrophic bacteria were tested in pots and an increase in the nitrogen content of the aerial part and an increase of dry mass and root volume was verified.

Studies carried out by Reis Junior, C. T. T. Machado, A. T. Machado, and Sodek (2008) on different maize genotypes show that the presence of bacteria considered endophytic increases the dry matter production and, in addition, nutrients utilization by the roots was more efficient, highlighting large concentrations of nitrogen in the analyzed roots. In addition, it highlights a greater accumulation of dry matter, besides a high protein content in inoculated plants resulting from the same experiment.

The objective of the present work was to evaluate the effect of inoculation of Burkholderia ambifaria growth promoting bacteria in maize plants, in vitro and in greenhouse, with distinct levels of nitrogen fertilization.

\section{Methodology}

\subsection{Site and Obtention of the Materials}

The tests were carried out in greenhouse and laboratory, coordinates $24^{\circ} 43^{\prime} 01.3^{\prime \prime} \mathrm{S} 53^{\circ} 47^{\prime} 07.9^{\prime \prime} \mathrm{W}$, of the Pontifical Catholic University of Paraná, Campus Toledo. The bacteria were supplied by the Federal University of Parana, Palotina Campus, and the hybrid PIONNER ${ }^{\circledR}$ 30F53 YH corn seeds, from Pionner, located in Toledo, Parana, Brazil.

The Burkholderia ambifaria strain was chosen for inoculation of a pre-test, where the strain promoted better results in the in vitro growth promotion parameter, when compared to the other bacteria tested. They were kept in petri dishes containing a specific Nfb solid culture medium (Dobereiner, V. L. D. Baldani \& J. I. Baldani, 1995) in the growth chamber. The choice of the hybrid PIONNER® 30F53 YH was based on its economic importance in the region, besides the excellent adaptability to the edaphoclimatic conditions.

For the preparation of the strain, initially a bacterial colony was transferred to a $50 \mathrm{ml}$ falcon tube, filled with 5 $\mathrm{ml}$ of DYGS liquid medium (Rodrigues Neto, Malavolta Junior, \& Victor, 1986), stored at $28{ }^{\circ} \mathrm{C}$ in shaker type incubator at $120 \mathrm{rpm}$, overnight, forming the pre-inoculum. The next day, $1 \mathrm{ml}$ of the pre-inoculum was transferred to $250 \mathrm{ml}$ Erlenmeyer flask containing $20 \mathrm{ml}$ of DYGS liquid medium, then returned to the shaker incubator at $120 \mathrm{rpm}$ at $28^{\circ} \mathrm{C}$ for two hours, until the bacterium reached the exponential phase (log) of growth, defined by the methodology of growth curves (Romeiro, 2001).

After growth, the cells mass present in $1 \mathrm{ml}$ was quantified by spectrophotometry at $660 \mathrm{~nm}$. For the inoculation the calculation to the concentration of $1.10^{6}$ cells per $\mathrm{ml}^{-1}$ was adequate, then calculated the volume necessary to inoculate 50 seeds, according to the one obtained in the growth curve.

Cells from bacteria, sufficient for the inoculum, were centrifuged, resuspended in saline solution $(0.9 \%)$ and inoculated into the 50 seeds, previously disinfected by asepsis in acidified hypochlorite, which consisted of washing for 20 minutes and then triple wash with distilled water, in the laminar flow chamber.

\subsection{Greenhouse and Laboratory}

For the greenhouse experiment 12-liter black poliethylen pots were filled with commercial Mecplant ${ }^{\circledR}$ substrate. After that, different doses of nitrogen, in the form of Super N (45\% of nitrogen), were applied, associated or not with bacterial inoculation, resulting in the treatments: without fertilization (Control); only Burkholderia ambifaria; $30 \mathrm{~kg} \mathrm{ha}^{-1}$ of nitrogen; $30 \mathrm{~kg} \mathrm{ha}^{-1}$ of nitrogen associated with Burkholderia ambifaria; $60 \mathrm{~kg} \mathrm{ha}^{-1}$ of nitrogen; $60 \mathrm{~kg} \mathrm{ha}^{-1}$ of nitrogen associated with Burkholderia ambifaria; $90 \mathrm{~kg} \mathrm{ha}^{-1}$ of nitrogen; $90 \mathrm{~kg} \mathrm{ha}^{-1}$ of nitrogen associated with Burkholderia ambifaria; $120 \mathrm{~kg} \mathrm{ha}^{-1}$ of nitrogen; $120 \mathrm{~kg} \mathrm{ha}^{-1}$ of nitrogen associated with 
Burkholderia ambifaria. The experimental design used was random blocks and which treatment had three replications. Six seeds were generated in each pot, after 15 days it was thinned to three plants per pot. Cultural dealings were carried out during the period of development of culture.

The plants were harvested at 30 and 45 days after the emergence. One plant per pot was evaluated on the following parameters: aerial dry weight in grams, aerial length in centimeters, epiphytic and endophytic population of the roots and colony forming units (CFU) per ml. After dry in the vertical oven of forced air at $65^{\circ} \mathrm{C}$ for 72 hours, aerial dry weight in gram and foliar nitrogen content in percentage were determined.

To evaluate root production in vitro, the adhesion essay was performed, the corn seeds pass through the same steps as the previous stage and then transferred to petri dishes filled with two autoclaved sheets of Germitest ${ }^{\circledR}$ for pre-germination. The dishes were wrapped with aluminum foil and stored in a BOD chamber at $25^{\circ} \mathrm{C}$ for 48 hours. In this period the pre-inoculum and inoculum of the bacteria were prepared as in the essay in greenhouse.

Then, the inoculation of the bacteria on the seeds was carried out, as in the greenhouse essay. After two hours the inoculated seeds were put into test tubes filled with $20 \mathrm{ml}$ of MS medium (Murashig \& Skoog, 1962) with and without nitrogen and all tubes had five centimeters of polypropylene spheres as a support.

Seven days after inoculation, the plants were removed from the test tubes and the following evaluations were performed: green shoot and root weight in grams, epiphytic and endophytic population counts of the root in CFU per $\mathrm{mL}$, root morphology. After drying in a vertical oven with forced circulation at $65^{\circ} \mathrm{C}$ for 72 hours, the dry weight of the aerial part and the root in grams and percentage of leaf nitrogen content were determined.

\subsection{Evaluations}

The counting method for epiphytic colonization consisted in, after the roots were previously washed, putting them in 1\% Chloramine $\mathrm{T}$ solution for 30 seconds then triple washed with distilled and autoclaved water, placed in eppendorf filled with $1000 \mu \mathrm{L}$ of saline solution. This eppendorf was placed in ultrasonic lavage for 1 minute, resulting in the dilution of $10^{-1}$, from this solution serial dilution was performed, removing $100 \mu \mathrm{L}$ of the solution and resuspending in new eppendorf with $900 \mu \mathrm{L}$ of saline solution until the dilution of $10^{-8}$, each dilution was placed in triplicate onto the petri dish filled with solid DYGS medium, subdivided into 8 equal parts.

Regarding the colonization count of the endophytic root population, it followed the previous methodology, however, after passing through $1 \%$ Chloramine $\mathrm{T}$ and washing, the roots were macerated in crucibles containing $1000 \mu \mathrm{L}$ of saline solution, after maceration, serial dilution was performed.

The plate counting method is based on the premise that, because of their small size and rate of division, the development of bacteria can be accounted by the population increase over a certain period, and not by the increase on its size, with different interpretations of what is growth, increase in population, and what is accumulation, size increase, considering the number of viable colonies, and not the total number of colonies (Romeiro, 2001).The dishes resulting from the epiphytic and endophytic counts, between 14 and 18 hours after preparation stored in an oven at $28{ }^{\circ} \mathrm{C}$, were counted in CFU dishes by the micro-drink methodology proposed by Romeiro (2001). Each dilution resulted in many viable CFUs present. These CFUs were counted and transformed by the equation defined by Romeiro (2001). The average of the three samples of each dilution performed was performed and, subsequently, the resulting value was converted to be shown in the table.

For the nitrogen content, the Kjeldahl method was used, based on the decomposition of the organic matter by the digestion of the sample at $400{ }^{\circ} \mathrm{C}$ with sulfuric acid concentrated, with copper sulfate as catalyst, accelerating the oxidation of the organic matter. The nitrogen present in the resulting acid solution is determined by steam distillation followed by titration with dilute boric acid $\left(\mathrm{H}_{3} \mathrm{BO}_{3}\right)$. The values obtained in the titration were transformed and demonstrated in percentage (Nogueira, Machado, Carmo, \& Ferreira, 2005).

For root morphology, three roots were randomly selected from each treatment. These roots were colored with bromophenol blue and observed in a 10 -fold electron microscope to visualize the present bacterial colony (Dall'Oglio Chaves, 2013).

\subsection{Statistic Analysis}

The data were submitted to the variance test (ANOVA) and, when significant, the means were compared by the Tukey test with $5 \%$ of probability to compare the inoculation effect of the growth promoting bacteria and the regression analysis for the different nitrogen doses by the statistical program SISVAR (Ferreira, 2010). 


\section{Results and Discussion}

During the greenhouse experiment, the parameters aerial part, foliar nitrogen assimilation and bacterial population present on the roots of corn plants were evaluated under conditions of presence and absence of nitrogen, inoculated or not with the bacterial strain, at 30 and 45 days after emergence.

Table 1. Growth promotion in corn plants in absence and bacterial presence, with different doses of nitrogen fertilization, evaluated at 30 and 45 days after planting in a greenhouse test

\begin{tabular}{|c|c|c|c|c|c|c|c|c|c|}
\hline \multirow{2}{*}{ Bacteria } & \multicolumn{9}{|c|}{ Nitrogen } \\
\hline & 0 & 30 & & 60 & & 90 & & 120 & \\
\hline \multirow[b]{3}{*}{ Absence } & \multicolumn{9}{|l|}{30 days } \\
\hline & \multicolumn{9}{|c|}{ Aerial part fresh weight $(\mathrm{g})$} \\
\hline & $13.08 \mathrm{a}^{*}$ & 18.55 & $\mathrm{a}$ & 6.11 & $\mathrm{a}$ & 17.33 & $\mathrm{a}$ & 26.70 & $\mathrm{a}$ \\
\hline \multirow[t]{2}{*}{ Presence } & $2.03 \mathrm{a}$ & 14.67 & $\mathrm{a}$ & 2.75 & $\mathrm{a}$ & 21.65 & $\mathrm{a}$ & 32.11 & $\mathrm{a}$ \\
\hline & \multicolumn{9}{|c|}{ Aerial part dry weight $(\mathrm{g})$} \\
\hline Absence & 1.15 & 1.39 & $\mathrm{a}$ & 0.57 & $\mathrm{a}$ & 1.26 & $\mathrm{a}$ & 1.84 & $\mathrm{a}$ \\
\hline \multirow[t]{2}{*}{ Presence } & $0.19 \quad \mathrm{~b}$ & 1.24 & $\mathrm{a}$ & 0.27 & a & 1.65 & a & 2.45 & $\mathrm{a}$ \\
\hline & \multicolumn{9}{|c|}{ Aerial part height $(\mathrm{cm})$} \\
\hline Absence & $59.87 \quad \mathrm{a}$ & 64.00 & $\mathrm{a}$ & 42.17 & $\mathrm{a}$ & 60.00 & $\mathrm{a}$ & 71.33 & $\mathrm{a}$ \\
\hline \multirow[t]{2}{*}{ Presence } & $31.00 \mathrm{~b}$ & 61.33 & $\mathrm{a}$ & 47.67 & a & 65.33 & a & 80.33 & $\mathrm{a}$ \\
\hline & \multicolumn{9}{|c|}{ Foliar nitrogen content $(\%)$} \\
\hline Absence & $4.40 \quad \mathrm{a}$ & 5.33 & $\mathrm{a}$ & 2.83 & $\mathrm{a}$ & 7.68 & $\mathrm{a}$ & 7.63 & $\mathrm{a}$ \\
\hline \multirow[t]{3}{*}{ Presence } & 5.60 & 5.28 & $\mathrm{a}$ & 2.40 & a & 7.89 & a & 8.53 & $\mathrm{a}$ \\
\hline & \multicolumn{9}{|l|}{45 days } \\
\hline & \multicolumn{9}{|c|}{ Aerial part fresh weight $(\mathrm{g})$} \\
\hline Absence & 59.98 a & 70.77 & $\mathrm{a}$ & 12.86 & $\mathrm{~b}$ & 179.74 & $\mathrm{a}$ & 111.28 & $\mathrm{a}$ \\
\hline \multirow[t]{2}{*}{ Presence } & $9.40 \quad b$ & 60.17 & $\mathrm{a}$ & 70.97 & a & 126.93 & $\mathrm{~b}$ & 141.23 & $\mathrm{a}$ \\
\hline & \multicolumn{9}{|c|}{ Aerial part dry weight (g) } \\
\hline Absence & $7.10 \quad \mathrm{a}$ & 7.73 & $\mathrm{a}$ & 3.54 & $\mathrm{a}$ & 14.80 & $\mathrm{a}$ & 12.52 & $\mathrm{a}$ \\
\hline \multirow[t]{2}{*}{ Presence } & 4.18 & 6.51 & a & 7.93 & $\mathrm{a}$ & 13.95 & a & 13.41 & $\mathrm{a}$ \\
\hline & \multicolumn{9}{|c|}{ Aerial part height $(\mathrm{cm})$} \\
\hline Absence & $94.17 \quad \mathrm{a}$ & 97.33 & $\mathrm{a}$ & 53.17 & $\mathrm{~b}$ & 130.00 & $\mathrm{a}$ & 120.67 & $\mathrm{a}$ \\
\hline \multirow[t]{2}{*}{ Presence } & $71.50 \quad \mathrm{a}$ & 86.67 & a & 101.00 & $\mathrm{a}$ & 123.50 & $\mathrm{a}$ & 130.83 & $\mathrm{a}$ \\
\hline & \multicolumn{9}{|c|}{ Foliar nitrogen content (\%) } \\
\hline Absence & 2.48 & 1.04 & a & 2.37 & a & 8.29 & $\mathrm{a}$ & 3.66 & $\mathrm{a}$ \\
\hline Presence & 2.24 & 1.39 & $\mathrm{a}$ & 1.95 & $\mathrm{a}$ & 4.16 & $\mathrm{~b}$ & 3.68 & $\mathrm{a}$ \\
\hline
\end{tabular}

Note. ${ }^{*}$ Lowercase letters represent the difference between rows, when significant at $5 \%$ probability.

At 45 days (Table 1), evaluating each dose with or without bacterial inoculation, it is possible to see that inoculated plants at the dose of $60 \mathrm{~kg} \mathrm{ha}^{-1}$ of nitrogen presented higher growth than the not inoculated plants at same dose. Yet, at the dose of $90 \mathrm{~kg} \mathrm{ha}^{-1}$ of nitrogen, the fresh weight was higher when not inoculated.

Some researches show that nitrogen application at different stages did not influence in the final corn yield (Ros, Salet, Porn, \& Machado, 2003; Gross, Pinho, \& Brito, 2006), however, the results show that, doses higher than $90 \mathrm{~kg} \mathrm{ha}^{-1}$ of nitrogen, with or without bacterial inoculation in the first development stages, promoted healthier plants, due to this characteristic the plants may become more resistant to biotic and abiotic inclement weather, making the investment part of a balanced system where more resistant plants recover or resist better to pests and diseases attacks.

According to Sangoi, Ernani, and Bianchet (2011), the application of nitrogen within the sowing can damage the germination of corn seeds, due to the salinity of the chemical fertilizer, that can make it harder for the seed to absorb water. 
For the height parameter (Table 1), in the absence of nitrogen fertilization, uninoculated plants stood out at 30 days. At 45 days plants inoculated with $60 \mathrm{~kg} \mathrm{ha}^{-1}$ of nitrogen showed a significantly difference when comparted to non-inoculated plants submitted to the same dose.

In addition to its participation in biochemical reactions (Coelho et al., 2003), the use of nitrogen in the initial stages of plant development must be based on the characteristic of the crop and the area, bringing benefits as occurred in the present research, where the highest the applied doses, the highest the obtained means, or no meaningful results to germination as occurred for Imolesi, E. D. R. Von Pinho, R. G. Von Pinho, Vieira, and Correa (2001), Argenta et al. (2003), and Sangoi, Ernani, and Bianchet (2011). Still, the results of this research suggest that the bacterium can act suppressing part of the nitrogen fertilization need in the initial stages, justifying the reduction of the lower dose of previous researches.
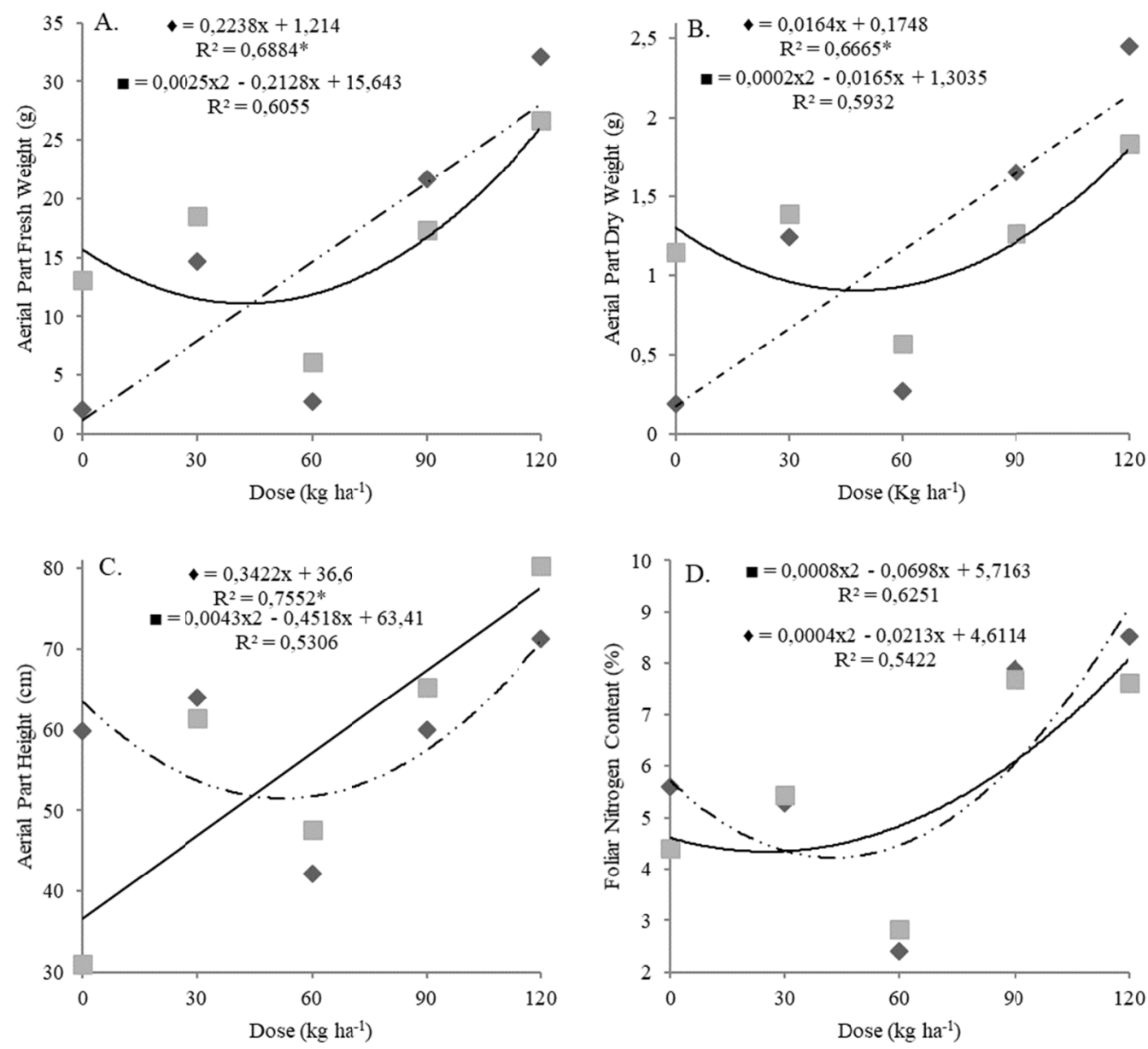

Figure 1. Growth promotion in maize plants submitted to different nitrogen doses, in the absence ( $\mathbf{\square})$ and bacterial presence $(\bullet-\quad$ - $)$ at 30 days after planting, under greenhouse conditions, for the parameters aerial part fresh weight (APFW) (A.), aerial part dry weight (APDW) (B.), aerial part height (APH) (C.), and foliar nitrogen content (N\%) (D.)

In the presence or absence of bacterial inoculation at 30 days (Figures $1 \mathrm{~A}$ and $1 \mathrm{~B}$ ) it is evidenced that the accumulation of fresh and dry weight presents a linear tendency when inoculated and quadratic when not inoculated, where increasing the dose resulted in gains for both parameters. Bacterial inoculation stod out in both factors, where inoculated plants showed higher averages than no inoculated at doses of 90 and $120 \mathrm{~kg} \mathrm{ha}^{-1}$ of nitrogen.

Working with Azospirillum brasilense on irrigated rice, Cardoso et al. (2014) analyzed root and stem samples, and concluded that bacteria are not influenced by the soil fertility, however, these nutritional factors may 
influence the activity of microorganisms, as occured in plants that received higher doses of nitrogen and bacterial inoculation in greenhouse.

Considering the functions of nitrogen in the plant and germination with the actions of bacteria in the soil and plant, one can ask if the different results according to the applied nitrogen doses and the development period of the plant do not indicate that there is a balance between the need for complementary fertilization to be supplied to inoculated plants. Endophytic associative bacteria do not compete for nutrients present in the rhizosphere soil because they internally colonize it. Because they are within the roots, their bioactive compounds are readily available to the plant organism, so the plant provides nutrients and habitat for the bacteria, while the bacteria promote growth and sanity for their host (Mariano et al., 2013), reducing the need for chemical fertilization.

As for the influence of the doses in height gain, of inoculated and non-inoculated plants (Figure 1C), the inversion of the two previous figures occurs, where the absence of bacterial inoculation presented a linear behavior and the presence a quadratic behavior, non-inoculated plants stand out with higher averages and uniform behavior to this parameter. For the foliar nitrogen content (Figure 1D), the absence and presence of bacterial inoculation showed a quadratic behavior, where the percentage decreased in intermediate doses and increased again in higher doses, the curves presented similar behavior among themselves.

Reis, Oliveira, V. L. D. Baldani, Olivares, and J. I. Baldani (2006) explain that many factors influence or inhibit the action of growth-promoting bacteria. This process requires high energy availability of the cell, the excess of nitrogen in the ammonium form can inhibit the nitrogenase activity.
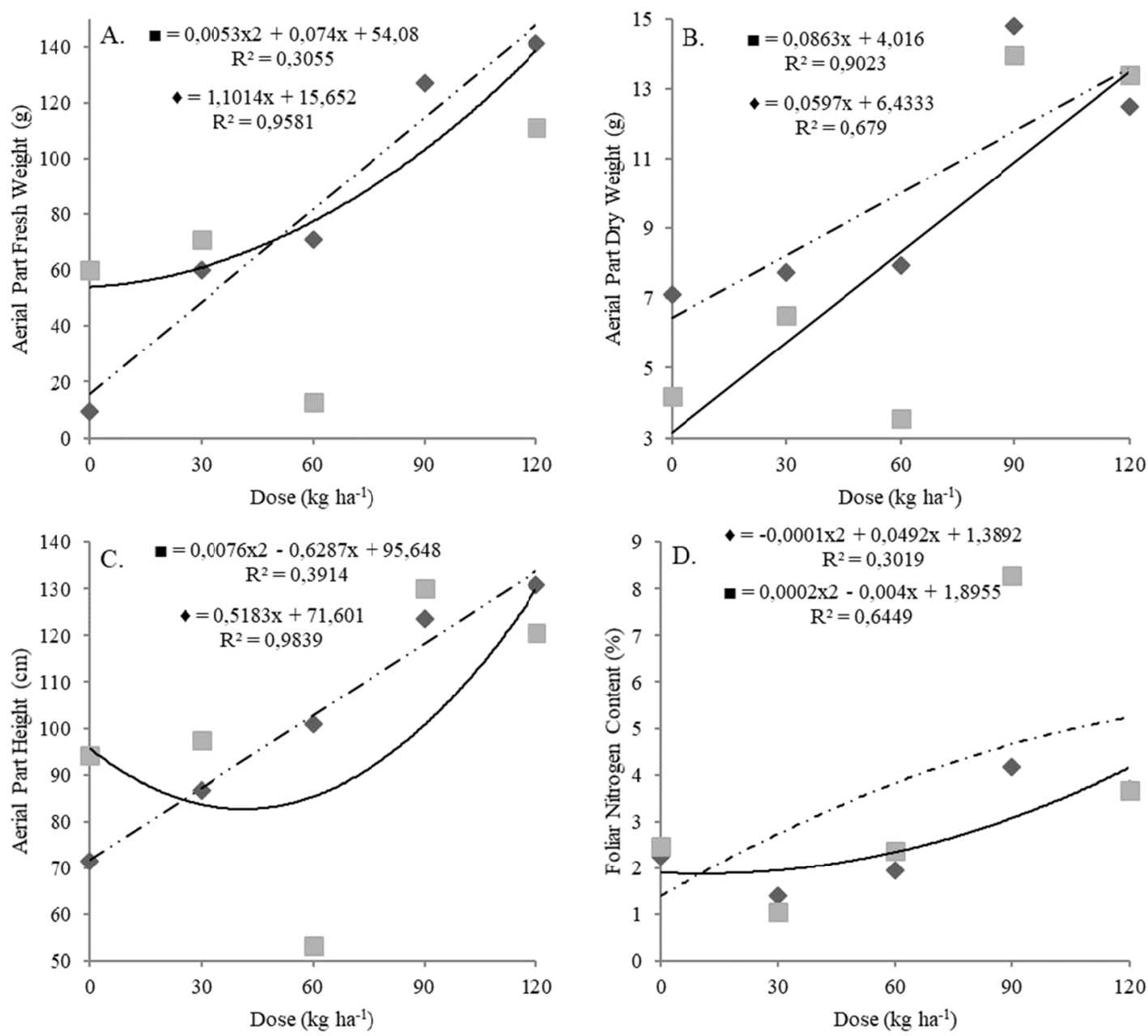

Figure 2. Growth promotion in maize plants submitted to different nitrogen doses, in the absence ( $\square$ ) and bacterial presence ( - - ) at 45 days after planting, under greenhouse conditions, for the parameters aerial part fresh weight (APFW) (A.), aerial part dry weight (APDW) (B.), aerial part height (APH) (C.), and foliar nitrogen content (N\%) (D.) 
Plants cultivated with $60 \mathrm{~kg} \mathrm{ha}^{-1}$ of nitrogen showed an abrupt reduction in their performance due to unidentified caterpillar, a pest that was controlled at the beginning of the symptoms. Mariano et al. (2013) concluded in their research that growth-promoting bacteria should be used in experiments of growth promotion and pathogen control to obtain an additional supply of $\mathrm{N}$ and induce resistance to multiple root and foliar tissues.

The accumulation of dry and fresh matter (Figures 2A and 2B) respectively, at 45 days after sowing highlights that the bacteria increased linearly the accumulation of dry mass, while the non-inoculated had a quadratic behavior. The accumulation of dry mass for both parameters has a linear tendency.

The recovery potential of the plants at $60 \mathrm{~kg} \mathrm{ha}^{-1}$ of nitrogen when inoculated presented a similar tendency to the other treatments, while non-inoculated presented lower performance. This characteristic opens a space for questioning how much of the use of growth-promoting bacteria can be beneficial for the recovery of plants that have suffered small pest attack.

Plants submitted o higher doses of nitrogen have greater availability of nutrients to do their basic metabolisms, being the nitrogen essential to many parameters, especially cellular development, considering that, as the dose increases, cell division increases, increasing thus development of the crop (Souza \& Fernandes, 2006).

Evaluating the endophityc population of the roots at 30 days in comparison with 45 days, it was observed a decrease in the coefficient of inoculation from 30 to 45 days after sowing, going from $10^{4}$ to $10^{2}$. However, it is noticeable the uniformity of the bacterial population at 45 days.

Table 2. Endophytic and epyphitic bacterial population in corn plants submitted to different doses of nitrogen fertilization at 30 and 45 days in greenhouse

\begin{tabular}{|c|c|c|c|c|c|}
\hline \multirow{2}{*}{ Bacteria } & \multirow{2}{*}{ Nitrogen } & \multicolumn{2}{|c|}{30 days } & \multicolumn{2}{|c|}{45 days } \\
\hline & & Epiphytic & Endophytic & Epiphytic & Endophytic \\
\hline & & \multicolumn{4}{|c|}{----------------------------------------- UFC mL ${ }^{-1}$------------------------------------- } \\
\hline \multirow{5}{*}{ Ausency } & 0 & $4.9 \times 10^{2}$ & $5.7 \times 10^{2}$ & $4.5 \times 10^{3}$ & $2.9 \times 10^{3}$ \\
\hline & 30 & $9.1 \times 10^{2}$ & $5.6 \times 10^{3}$ & $4.3 \times 10^{2}$ & $6.5 \times 10^{2}$ \\
\hline & 60 & $1.1 \times 10^{3}$ & $5.6 \times 10^{2}$ & $3.4 \times 10^{2}$ & $4.2 \times 10^{2}$ \\
\hline & 90 & $3.0 \times 10^{1}$ & $4.4 \times 10^{2}$ & $6.4 \times 10^{2}$ & $4.1 \times 10^{2}$ \\
\hline & 120 & $1.5 \times 10^{2}$ & $1.7 \times 10^{3}$ & $8.0 \times 10^{2}$ & $1.7 \times 10^{3}$ \\
\hline \multirow{5}{*}{ Presence } & 0 & $3.6 \times 10^{3}$ & $4.0 \times 10^{4}$ & $5.3 \times 10^{3}$ & $9.2 \times 10^{3}$ \\
\hline & 30 & $2.7 \times 10^{4}$ & $1.3 \times 10^{3}$ & $5.5 \times 10^{2}$ & $8.6 \times 10^{2}$ \\
\hline & 60 & $1.3 \times 10^{2}$ & $4.2 \times 10^{2}$ & $9.7 \times 10^{2}$ & $5.1 \times 10^{2}$ \\
\hline & 90 & $7.5 \times 10^{1}$ & $2.1 \times 10^{2}$ & $4.5 \times 10^{2}$ & $5.1 \times 10^{2}$ \\
\hline & 120 & $3.0 \times 10^{3}$ & $8.5 \times 10^{2}$ & $4.7 \times 10^{2}$ & $1.8 \times 10^{2}$ \\
\hline
\end{tabular}

At 30 after sowing and $30 \mathrm{~kg} \mathrm{ha}^{-1}$ of nitrogen (Table 2), the presence of bacteria presented the highest epiphytic population of $2.7 \times 10^{4} \mathrm{CFU} \mathrm{ml}^{-1}$ and the absence of nitrogen fertilization with inoculation presented the largest endophytic population of $4.0 \times 10^{4} \mathrm{CFU} \mathrm{mL}^{-1}$. At 45 days after sowing, the inoculated plants without fertilization had the highest epiphytic and endophytic population of $5.3 \times 10^{3}$ and $9.2 \times 10^{3}$ respectively.

Nitrogen has, among others, the function of stimulating the development of corn roots, higher doses may make bacterial colonization unnecessary or slower, making it difficult the colonization (Mercante, Hungria, Mendes, \& Reis Junior, 2011).

Bacteria from the genus Burkholderia have great ability to compete with plant exudates, which facilitates root colonization, besides having the capacity to produce antimicrobial compounds, which makes it superior when competing with other soil microorganisms, with the potential to provide some nutrients and the capacity to grow in more than 200 organic compounds (Luvizotto, 2008).

Inoculated plants when submitted to higher doses of fertilization showed smaller amount of bacterial population in their roots, it is noteworthy that the control showed larger bacterial populations when compared to the other treatments, which reduced according to the increase of the applied fertilization.

Because they can survive within the rhizosphere in a symbiotic way (Reis, Oliveira, V. L. D. Baldani, Olivares, \& J. I. Baldani, 2006), these bacteria will develop in greater or lesser quantitys according to the need of the plants, although the initially higher doses help on its initial establishment and penetration in the corn rots, due to greater cellular loosening in successive divisions (Faquin, 1994), in the posterior days, these doses end up 
turning its activity slower, making the control stand out because of the lower nitrogen availability of easy assimilation, since the beginning of its development, causing the bacteria to have high activity from the beginning of their establishment, because there was a greater need for help from them.

Besides these factors, being an ecologically complex environment, the rhizosphere has natural enemies of the bacteria, the bacterial colonization capacity is influenced by: antibiotic production, used substrate, compatibility of the bacteria with the rhizosphere, in addition the bacterial population growth rate (Barbosa, Consalter, \& Motta, 2012).

Studies on inoculated legumes have highlighted that high doses of nitrogen at sowing have made the inoculation less efficient, because of the high availability of nutrients, the bacteria inoculate less intensely the plants, thus diminishing their potential (Zilli et al., 2008). With the results obtained, is possible to speculate if this characteristic is not repeated in grasses submitted to the same characteristics.

During the experiment in the laboratory (Table 3) the parameters of aerial part development, root and bacterial population were analyzed in seedlings grown in vitro under conditions of presence and absence of nitrogen, inoculated or not with the bacterial strain Burkholderia ambifaria.

Table 3. Growth promotion of corn plants in the presence or absence of bacteria, in culture medium in the presence or abscence of nitrogen at 14 days in lab

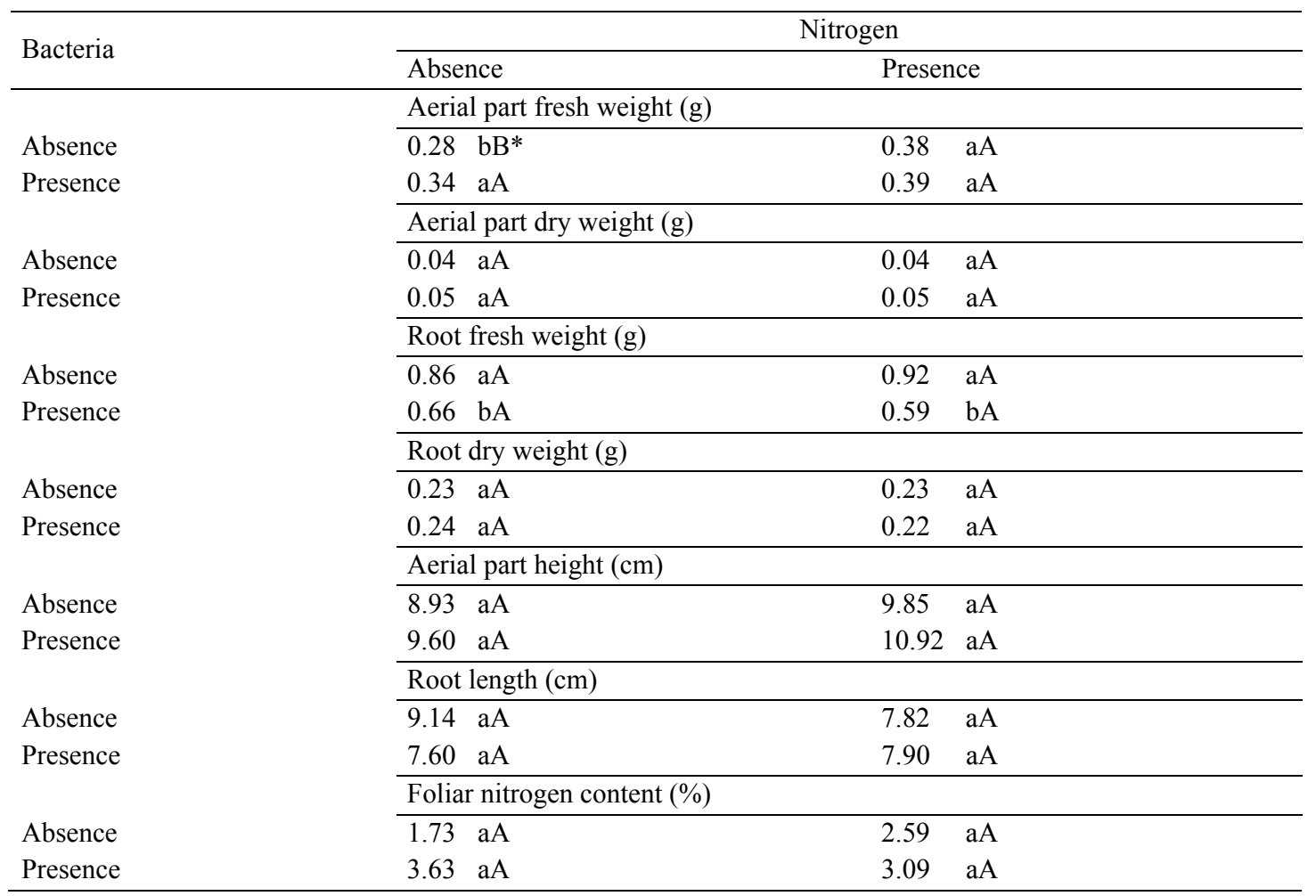

Note. ${ }^{*}$ Lowercase letters represent the difference between rows, uppercase letters the difference between columns, when significant at $5 \%$ probability.

Plants cultivated in the absence of nitrogen and in the presence of bacteria differed statistically from the ones cultivated in the absence of nitrogen and in the bacterial population, for the aerial fresh weight parameter (Table 3 ). When with nitrogen, the uninoculated plants were statistically superior to the others for roots fresh and dry weight parameters.

Among the potentials associated with endophytic bacteria, the increase of stem and shoot biomass is among the most mentioned characteristics in experiments, as well as increase of the number of root hairs (Pillay \& Nowak, 1997). Regarding the epiphytic and endophytic population (Table 4), among the results obtained in vitro in the presence and absence of nitrogen, with or without bacteria, the asepsis efficiency is highlighted, and both variables classified as control did not present bacterial presence. 
Epiphytically and endophytically (Table 4), inoculated plants in the absence of nitrogen had a higher quantity of colony forming unities in two roots, $1.0 \times 10^{6}$ epiphytically and $1.1 \times 10^{7}$ endophytically. Bacterial strains belonging to the genus Burkholderia spp, have mandatory endophytic colonization characteristics (J. Baldani, Caruso, V. L. Baldani, Goi, \& Dobereiner, 1997), this characteristic was confirmed both in the presence or absence of nitrogen, with greater number of colonies internally than externally of the roots.

Table 4. Epiphytic and endophytic bacterial population in corn plants submitted to culture médium with and without nitrogen at lab

\begin{tabular}{lllc}
\hline Bacteria & Nitrogen & Epiphytic & Endophytic \\
\hline \multirow{2}{*}{ Absence } & & --1.00 & 0.00 \\
& Absence & 0.00 & $1.1 \times 10^{7}$ \\
Presence & Presence & $1.0 \times 10^{6}$ & 0.00 \\
& Absence & 0.00 & $1.6 \times 10^{6}$ \\
\hline
\end{tabular}

Microorganisms with endophytic potential are attracted from the soil to the roots of plants by the release of organic exudates (chemotaxis) and thus penetrate the root tissues, reaching different organs such as leaves, stems and flowers. This tissue penetration is performed by the release of hydrolytic enzymes such as cellulases and pectinases or by natural openings in the plant (Hallmann, Quatt-Hallmann, Mahafee, \& Kloepper, 1997).

Barreti, Romeiro, Mizubuti, and Souza (2009), conclude in their experiment with 150 endophytic isolates that the growth promoting bacteria being evaluated in tomato plants, promoted greater growth in height and root, besides a greater leaf area, fresh and dry matter weight.

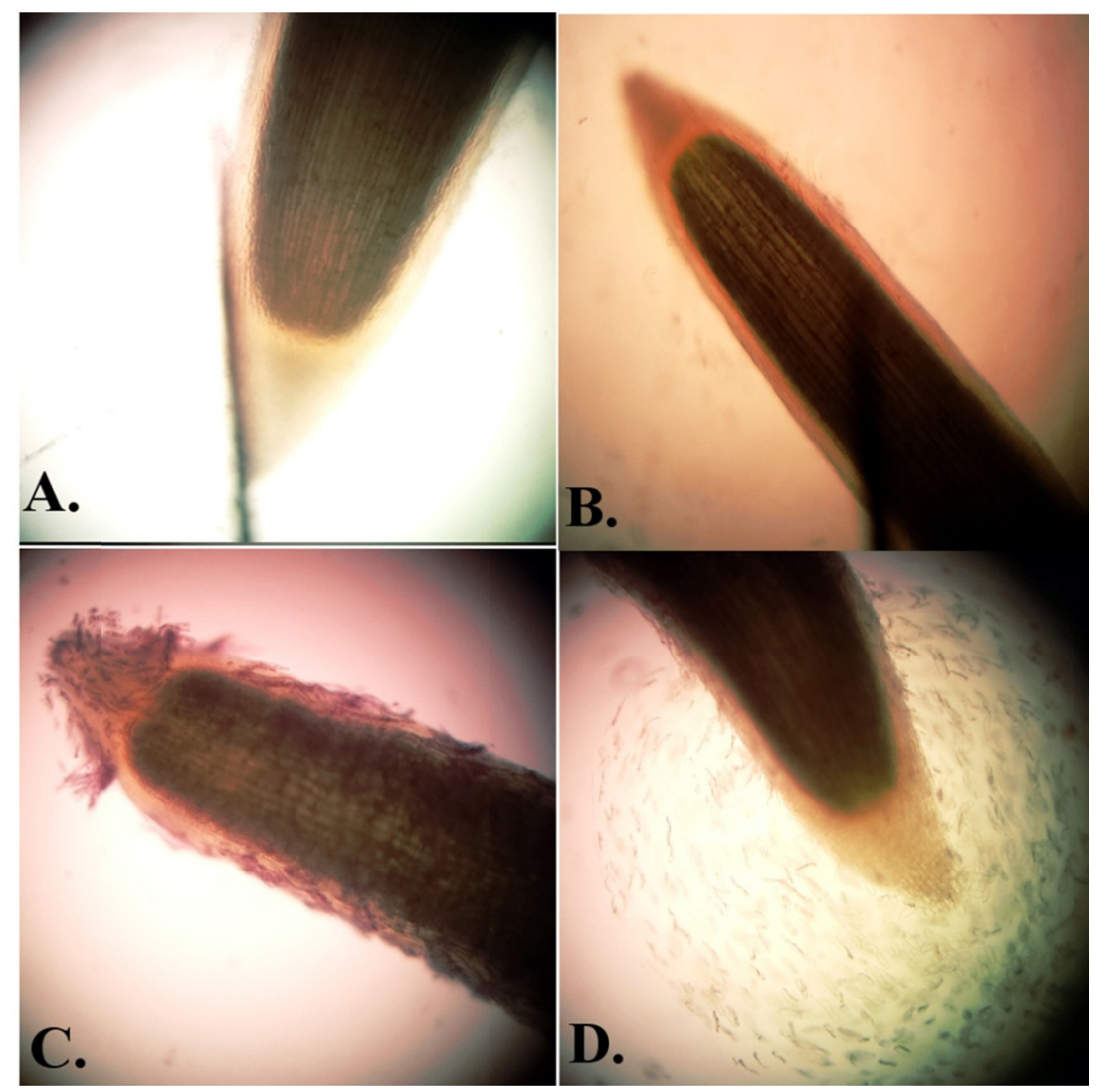

Figure 3. Root morphology comparing maize plants inoculated with B. ambifaria and its control in the presence and absence of nitrogen, being: control without nitrogen (A), control with nitrogen (B), Burkholderia ambifaria without nitrogen (C), and Burkholderia ambifaria with nitrogen (D)

Source: The authors, 2015. 
The root morphology (Figure 3D) shows that the plants inoculated with nitrogen in the culture medium present a great bacterial activity around their roots, while inoculated seeds in the absence of nitrogen (Figure 3C) presented a lower epiphytic population, however, the count of endophytic population (Table 4) was higher than the other treatments, finally Figures A and B, which represent the controls, do not present any bacterial population.

The inoculation with growth promoting bacteria in Poaceae present an enormous potential for study, even without a definition of the best bacteria for each cultivated specie, the tests present great potential, demonstrating that in a near future, the use of agricultural inputs cam be reduced, opening space to a cheaper substitute that causes less damage to the environment.

Mariano et al. (2013) cite in their study that bacteria can be used as strategies that aim to increase production, reducing the damages to the environment, where, in addition to financial factors, the social and political factors of each region are considered. As native to the soil, bacteria do not interfere with the ecological balance, thus being able to fit into the perspectives of organic and sustainable agriculture.

In addition to the sustainable characteristics, it is important to highlight the increase of productivity and profitability in inoculated plants, such as the results obtained in the works of: Sala, Cardoso, Freitas, and Silveira (2008) in wheat plants, where inoculation resulted in dose reduction (2004), where corn plants associated with growth promoting bacteria reduced the need for nitrogen fertilization, by Silveira, Gome, Mariano, and Silva Neto (2004), with the improvement of cucumber seedlings when the seeds were inoculated with growth-promoting bacteria of Sabino, Freitas, Guimarães, Bandani, and Conquista (2012), resulting in increased biomass and better initial development of rice seedlings, among others highlighting that the potential of growth promoting organisms can extend to differentiated families, with the Cucurbitaceous, in the case of the cucumber, as has happened with the Leguminosae.

The use of plant growth promoting bacteria, associated or not to different doses of nitrogen fertilization, promoted the development of some morphological characteristics of the maize crop. Studies of bacterial action in distinct phases of the crop are essential for understanding the relationship between the plant and the microorganism, aiming the efficient use of this characteristic in favor of the final productivity and use of natural resources.

\section{References}

Alves, G. C., \& Reis, V. M. (2011). Identificação de genótipos de milho responsivos à inoculação com a estirpe BR 11417 de Herbaspirillum seropedicae. Seropédica, Brazil: Embrapa Agrobiologia.

Argenta, G., Silva, P. D., Fosthofer, E. L., Strieder, M. L., Suhre, E., \& Teichmann, L. L. (2003). Adubação nitrogenada em milho pelo monitoramento do nível de nitrogênio na planta por meio do clorofilômetro. Revista Brasileira de Ciência do Solo, 27(1), 109-119. https://doi.org/10.1590/s0100-06832003000100012

Baldani, J. I., \& Baldani, V. L. (2005). History on the biological nitrogen fixation research in graminaceous plants: Special emphasis on the Brazilian experience. Anais da Academia Brasileira de Ciências, 77(3), 549-579. https://doi.org/10.1590/s0001-37652005000300014

Baldani, J., Caruso, L., Baldani, V. L., Goi, S. R., \& Döbereiner, J. (1997). Recent advances in BNF with non-legume plants. Soil Biology and Biochemistry, 29(5), 911-922. https://doi.org/10.1016/s0038-0717 (96)00218-0

Barbosa, J. Z., Consalter, R., \& Motta, A. C. V. (2012). Fixação biológica de nitrogênio em Poaceae. Evidência-Ciência e Biotecnologia, 12(1), 7-18.

Barretti, P. B., Romeiro, R. D. S., Mizubuti, E. S. G., \& Souza, J. T. D. (2009). Seleção de bactérias endofíticas de tomateiro como potenciais agentes de biocontrole e de promoção de crescimento. Ciencia Agrotecnologia, 33(1), 2038-2044. https://doi.org/10.1590/s1413-70542009000700057

Canuto, E. D. L., Salles, J. F., Oliveira, A. L. M., Perin, L., Reis, V. M., \& Baldani, J. I. (2003). Respostas de plantas micropropagadas de cana-de-açúcar à inoculação de bactérias diazotróficas endofíticas. Agronomia, $37(2), 67-72$.

Cardoso, I. C. M., Klauberg Filho, O., Mariotto, J. R., Miquelluti, D. J., Vicente, D., \& Neves, A. N. (2014). Ocorrência de bactérias endofíticas do gênero Azospirillum em arroz irrigado no estado de Santa Catarina. Revista de Ciências Agroveterinárias, 9(2), 178-186. 
Coelho, C. H. M., Medeiros, A. F., Polidoro, J. C., Xavier, R. P., Resende, A., \& Quesada, D. M. (2003). Identificação de genótipos de cana-de-açúcar quanto ao potencial de contribuição da fixação biológica de nitrogênio. Agronomia, 37(2), 37-40.

Cruz, J. C., Pereira Filho, I. A., Alvarenga, R. C., Gontijo Neto, M. M., Viana, J. H. M., de Oliveira, M. F., \& Santana, D. P. (2006). Manejo da cultura do milho (Circular Técnica). Sete Lagoas, Brazil: Embrapa Milho e Sorgo.

Dall'Oglio Chaves, E. I. (2013). Diversidade de Bactérias Endofiticas Obtidas de Solos do Oeste do Paraná Usando Milho e Trigo como Planta Isca (Unpublished doctoral dissertation, Universidade Estadual do Oeste do Paraná, Marechal Candido Rondon, Brazil).

Dartora, J., Guimarães, V. F., Marini, D., \& Sander, G. (2013). Adubação nitrogenada associada à inoculação com Azospirillum brasilense e Herbaspirillum seropedicae na cultura do milho. Revista Brasileira de Engenharia Agricola e Ambiental-Agriambi, 17(10), 1023-1029. https://doi.org/10.1590/s1415-436620130 01000001

Döbereiner, J., Baldani, V. L. D., \& Baldani, J. I. (1995). Como isolar e identificar bactérias diazotróficas de plantas não-leguminosas (1st ed.). Itaguai, Brazil: Embrapa SPI.

Faquin, V. (1994). Nutrição Mineral de Plantas (1st ed.). Lavras, Brazil: ESAL/FAEPE.

Ferreira, D. F. (2010). SISVAR-Sistema de análise de variância (v. 5.3). Lavras, Brazil: UFLA.

Figueiredo, M. V. B., Sobral, J. K., Stamford, T. L. M., \& Araújo, J. M. (2010). Bactérias promotoras do crescimento de plantas: estratégia para uma agricultura sustentável. Biotecnologia aplicada à agricultura: textos de apoio e protocolos experimentais. Brasilia, Brazil: Embrapa Agrobiologia.

Gross, M. R., Pinho, R. G. V., \& Brito, A. D. (2006). Adubação nitrogenada, densidade de semeadura e espaçamento entre fileiras na cultura do milho em sistema plantio direto. Ciênc. Agrotec., 30(3), $387-393$. https://doi.org/10.1590/s1413-70542006000300001

Hallmann, J., Quadt-Hallmann, A., Mahaffee, W. F., \& Kloepper, J. W. (1997). Bacterial endophytes in agricultural crops. Canadian Journal of Microbiology, 43(10), 895-914. https://doi.org/10.1139/m97-131

Imolesi, A. S., Von Pinho, E. D. R., Von Pinho, R. G., Vieira, M. G. G. C., \& Corrêa, R. S. B. (2001). Influência da adubação nitrogenada na qualidade fisiológica das sementes de milho. Ciência e Agrotecnologia, 25(5), 1119-1126.

Kuss, A. V., Kuss, V. V., Lovato, T., \& Flôres, M. L. (2007). Fixação de nitrogênio e produção de ácido indolacético in vitro por bactérias diazotróficas endofíticas. Pesquisa Agropecuária Brasileira, 42(10), 1459-1465. https://doi.org/10.1590/s0100-204x2007001000013

Luvizotto, D. M. (2008). Caracterização fisiológica e molecular de Burkholderia spp. associadas às raizes de caa-de-açúcar (Doctoral dissertation, Universidade de São Paulo, Piracicaba, Brazil). Retrieved from http://www.teses.usp.br/teses/disponiveis/11/11138/tde-15122008-144208/pt-br.php

Marcos, F. C. C. (2012). Influência de bactérias endofíticas na fisiologia de plantas de cana-de-açúcar sob restrição hídrica (Master thesis in Tropical and Subtropical Agriculture. Agronomic Institute of Campinas, Campinas, Brazil). Retrieved from http://www.iac.sp.gov.br/areadoinstituto/posgraduacao/dissertacoes/ pb1211410\%20Fernanda\%20Castro\%20Correia\%20Marcos.pdf

Mariano, R. D. L. R., Silveira, E. B., Assis, S. M. P., Gomes, A. M. A., Nascimento, A. R. P., \& Donato, V. M. T. S. (2013). Importância de bactérias promotoras de crescimento e de biocontrole de doenças de plantas para uma agricultura sustentável. Anais da Academia Pernambucana de Ciência Agronômica, 1(1), 89-111.

Marques Júnior, R. B., Canellas, L. P., Silva, L. G. D., \& Olivares, F. L. (2008). Promoção de enraizamento de microtoletes de cana-de-açúcar pelo uso conjunto de substâncias húmicas e bactérias diazotróficas endofíticas. Revista Brasileira de Ciência do Solo, 32(3), 1121-1128. https://doi.org/10.1590/s0100-0683 2008000300020

Mercante, F. M., Hungria, M., Mendes, I. D. C., \& Reis Junior, F. B. (2011). Estratégias para aumentar a eficiência de inoculantes microbianos na cultura da soja. Dourados, Brazil: Embrapa Agropecuária Oeste-Comunicado Técnico (INFOTECA-E).

Murashige, T., \& Skoog, F. (1962). A revised medium for rapid growth and bio assays with tobacco tissue cultures. Physiologia Plantarum, 15(3), 473-497. https://doi.org/10.1111/j.1399-3054.1962.tb08052.x 
Nogueira, A. D. A., Machado, P. L. O. A., Carmo, C. D. S., \& Ferreira, J. R. (2005). Manual de laboratórios: Solo, água, nutrição vegetal, nutrição animal e alimentos. São Carlos, Brazil: Embrapa Pecuária Sudeste.

Pereira, A. D. A., Silva, M. D. B., Oliveira, J. D. S., Ramos, A. D. S., Freire, M. B. G. S., Freire, F. J., \& Kuklinsky-Sobral, J. (2012). Salinity influence on the growth and production of indole acetic acid by endophytic Burkholderia spp. from sugarcane. Bioscience Journal, 28(Suppl. 1), 112-121.

Pillay, V. K., \& Nowak, J. (1997). Inoculum density, temperature, and genotype effects on in vitro growth promotion and epiphytic and endophytic colonization of tomato (Lycopersicon esculentum L.) seedlings inoculated with a pseudomonad bacterium. Canadian Journal of Microbiology, 43(4), 354-361. https://doi.org/10.1139/m97-049

Quadros, P. D. D. (2009). Inoculação de Azospirillum spp. em sementes de genótipos de milho cultivados no Rio Grande do Sul (Master thesis, Universidade Federal do Rio Grande do Sul, Porto Alegre, Brazil). Retrieved from http://www.lume.ufrgs.br/handle/10183/17076

Reis Junior, F. B. D., Machado, C. T. T., Machado, A. T., \& Sodek, L. (2008). Inoculação de Azospirillum amazonense em dois genótipos de milho sob diferentes regimes de nitrogênio. Revista Brasileira de Ciência do Solo, 32(3), 1139-1149. https://doi.org/10.1590/s0100-06832008000300022

Reis, V. M., Oliveira, A. D. M., Baldani, V. L. D., Olivares, F. L., \& Baldani, J. I. (2006). Fixação biológica de nitrogênio simbiótica e associativa. Nutrição Mineral de Plantas (1st ed.). Viçosa, Brazil: Sociedade Brasileira de Ciência do Solo.

Rodrigues Neto, J., Malavolta Junior, V. A., \& Victor, O. (1986). Meio simples para o isolamento e cultivo de Xanthomonas campestris pv. citri tipo B. Summa Phytopathol, 12(1-2), 32.

Romeiro, R. D. S. (2001). Métodos em bacteriologia de plantas (1st ed.). Viçosa, Brazil: UFV.

Ros, C. O., Salet, R. L., Porn, R. L., \& Machado, J. N. C. (2003). Disponibilidade de nitrogênio e produtividade de milho e trigo com diferentes métodos de adubação nitrogenada no sistema plantio direto. Ciência Rural, 33(5), 799-804. https://doi.org/10.1590/s0103-84782003000500002

Sabino, D. C. C., Ferreira, J. S., Guimarães, S. L., Baldani, V. L. D., \& Conquista, V. (2012). Bactérias diazotróficas como promotoras do desenvolvimento inicial de plântulas de arroz. Enciclopédia Biosfera, $8(15), 2337-2345$.

Sala, V. M. R., Cardoso, E. J. B. N., Freitas, J. G. D., \& Silveira, A. P. D. (2008). Novas bactérias diazotróficas endofíticas na cultura do trigo em interação com a adubação nitrogenada, no campo. Revista Brasileira de Ciência do Solo, 32(3), 1099-1106. https://doi.org/10.1590/s0100-06832008000300018

Sangoi, L., Ernani, P. R., \& Bianchet, P. (2011). Desenvolvimento inicial do milho em função de doses e fontes de nitrogênio aplicadas na semeadura. Biotemas, 22(4), 53-58. https://doi.org/10.5007/2175-7925

Santos, J. F. D., Sacramento, B. L. D., Mota, K. N. A. B., Souza, J. T. D., \& Azevedo Neto, A. D. D. (2014). Sunflower growth according to seed inoculation with endophytic bacteria. Pesquisa Agropecuária Tropical, 44(2), 142-150. https://doi.org/10.1590/s1983-40632014000200008

Silva, J. R. C., Souza, R. M. D., Zacarone, A. B., Silva, L. H. C. P. D., \& Castro, A. M. D. S. (2008). Control with endophytic bacteria and in vitro inhibition of Pseudomonas syringae pv tomato, agent of bacterial speck of tomato. Ciência e Agrotecnologia, 32(4), 1062-1072. https://doi.org/10.1590/s1413-7054200800 0400005

Silveira, E. B., Gomes, A. M., Mariano, R. L., \& Silva Neto, E. B. (2004). Bacterização de sementes e desenvolvimento de mudas de pepino. Horticultura Brasileira, 22(2), 217-221. https://oi.org/10.1590/ s0102-05362004000200011

Souza, R. S., \& Fernandes, M. S. (2006). Nitrogênio. Nutrição Mineral de Plantas (1st ed.). Viçosa, Brazil: Sociedade Brasileira de Ciência do Solo.

Taiz, L., \& Zeiger, E. (2013). Fisiologia vegetal (5th ed.). Porto Alegre, Brazil: Artmed.

Zilli, J. É., Marson, L. C., Marson, B. F., Gianluppi, V., Campo, R. J., \& Hungria, M. (2008). Soybean inoculation by spraying Bradyrhizobium over plants. Pesquisa Agropecuária Brasileira, 43(4), $541-544$. https://doi.org/10.1590/s0100-204x2008000400014 


\section{Copyrights}

Copyright for this article is retained by the author(s), with first publication rights granted to the journal.

This is an open-access article distributed under the terms and conditions of the Creative Commons Attribution license (http://creativecommons.org/licenses/by/4.0/). 